Int. Agrophys., 2021, 35, 343-355

\title{
Tritordeum - the content of basic nutrients in grain and the morphological and anatomical features of kernels**
}

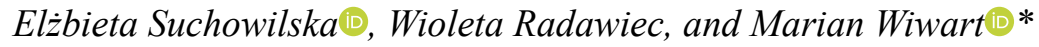 \\ Department of Genetics, Plant Breeding and Bioresource Engineering, Faculty of Agriculture and Forestry, \\ University of Warmia and Mazury in Olsztyn, pl. Łódzki 3, 10-724 Olsztyn, Poland
}

Received September 17, 2021; accepted December 6, 2021

\begin{abstract}
The nutrient content and the morphological and anatomical features of kernels were compared for 11 breeding lines of tritordeum and three Triticum durum cultivars. The kernel shape descriptors were examined using digital image analysis, and the contents of four basic nutrients were determined. Tritordeum grain had a significantly higher content of protein, fat, ash and fibre than durum wheat grain. In turn, the values of one kernel weight, kernel thickness and hardness were significantly lower in tritordeum. Tritordeum kernels are elongated, relatively small, with a deep crease and a small cross-sectional area. All lines differed considerably with regard to the examined phenotypic attributes. Tritordeum lines and the reference cultivars were most effectively distinguished based on fibre content, spike length, spikelet number per spike, and kernel number and weight per spike. One kernel weight, whole kernel area, crease depth, and the distance from the bottom of the crease to the kernel edge were the least distinguishing traits. The results indicate that tritordeum grain can accumulate more than $19 \%$ protein and $43 \%$ more fibre than durum wheat in Central Europe. The examined tritordeum lines are highly promising despite the fact that their yield potential is twice lower compared to modern $T$. durum cultivars.

Keyw ords: tritordeum, basic nutrients, cross section, grain, shape analysis
\end{abstract}

\section{INTRODUCTION}

Cereals have been the main source of calories for humans since agriculture began. Wheat-based products have a high nutritional value and sensory quality, they provide around

*Corresponding author e-mail: marian.wiwart@uwm.edu.pl

**This work was financially supported by Minister of Education and Science in the range of the program entitled "Regional Initiative of Excellence" for the years 2019-2022, Project No. 010/ RID/2018/19, amount of funding 12.000.000 PLN. two-thirds of the calories in the human diet and are the most important ingredient in the diet of contemporary societies (Montesano et al., 2020). Since the beginning of the twentieth century, cereal breeders have been focusing their efforts on interspecific hybrids to obtain new cereals with a high content of phytochemicals, improved agronomic performance and high processing quality (Giordano et al., 2019). Wheat and barley have been common crops worldwide for millennia, whereas tritordeum is a relatively new crop and an alternative cereal with unique properties and major health benefits. Cultivated tritordeum (x Tritordeum martinii A. Pujadas, nothosp. nov.) is a fertile hexaploid plant $(2 n=6 x=42$, AABBHchHch) that was developed in the late 1970s in Spain by crossing durum wheat (Triticum durum Desf.) with wild barley (Hordeum chilense Roem. and Schult.), hence the name Trit(icumH)ordeum. The genome structure of tritordeum originated from the chromosomes of $H$. chilense $(2 \mathrm{n}=2 \mathrm{x}=14, \mathrm{HchHch})$ and . durum $(2 \mathrm{n}=4 \mathrm{x}=28$, AABB) (Martín and Sánchez-Monge, 1980). The cytoplasm is derived from the female parent $H$. chilense. Hordeum chilense is a wild diploid barley originating from South America, and it belongs to the section Anisolepis (Bothmer et al., 1995). Tritordeum is considered to be a genetic bridge that combines the useful properties of barley and wheat, including the composition and structure

(C) 2021 Institute of Agrophysics, Polish Academy of Sciences (c) (1) () $\odot$ 
of storage proteins, carotenoid content (Ballesteros et al., 2005; Martin et al., 2000) and tolerance to drought and salinity (Villegas et al., 2010). In recent years, tritordeum has been introduced to the European markets as an alternative to traditional cereals. The carotenoid content is 5-6 times higher in tritordeum than in durum wheat grain. This trait has been inherited from wild barley, and it suggests that tritordeum has a high potential to become a functional food (Martín et al., 1999). The grain of this cereal is mainly used to make flour, bread or groats. Tritordeum is also characterized by its favourable agronomic performance and interesting physiological traits related to nitrogen metabolism, a process that is essential for the growth and yield of most crops (Vaquero et al., 2018). At present, tritordeum is available on several European and non-European markets, and its popularity is on the rise in Spain, Italy and Portugal. Tritordeum has been commercialized by the Spanish company Agrasys S.L. (https://www.agrasys.es/en/). The genotypes developed are still characterized by much lower yields than other small-grain cereals, which is the main barrier to the widespread cultivation of tritordeum. More than 250 primary lines of tritordeum have been developed to date (Erlandsson, 2010). Several commercial lines of tritordeum have been registered in recent years. The first commercial line was HT1608 which was registered in 2008 under the trade name Vivagran. Lines JB1 and JB3 were registered in 2010 as varieties under the names Aucan and Bulel (Giordano et al., 2019).

Despite the information outlined above, little is known about the morphometric characteristics and nutritional value of tritordeum grain. Therefore, the aim of this study was to examine the morphometric attributes of whole kernels and kernel cross-sections using digital image analysis, in order to determine the content of basic nutrients in tritordeum grain, and to examine the variation in tritordeum yield components.

\section{MATERIALS AND METHODS}

The experimental material consisted of eleven breeding lines of tritordeum and three cultivars of Triticum durum Desf. as a reference material (Table 1). The field experiment was conducted at the Agricultural Experiment Station

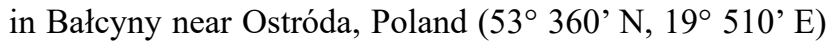
using optimal soil for wheat cultivation. The experiment had a random block design with two replicates. The plot size was $9 \mathrm{~m}^{2}$. NPK fertilizer was applied before sowing at a rate of $60 / 25 / 80 \mathrm{~kg} \mathrm{ha}^{-1}$. The seeds were not dressed, and fungicides and insecticides were not applied during the growing season. The grain for all of the analyses was harvested at the full maturity stage.

The following yield components and morphological traits were determined for the harvested tritordeum kernels in a biometric analysis: kernel and spikelet number per
Table 1. Tritordeum breeding lines and T. durum cultivars examined in the experiment

\begin{tabular}{ll}
\hline $\begin{array}{l}\text { Breeding line/ } \\
\text { cultivar }\end{array}$ & Origin \\
\hline HT 440 & Tritordeum \\
HT 129 & \\
HTC 2083 & \\
HTC 2083* & \\
HTC 2060 & Institute of Sustainable Agriculture \\
HT 157 & (CSIC, Spain) \\
HT 352 & \\
JB3 & \\
HT 438 & \\
HT 444 & \\
HTC 1324 & \\
Floradur & $\begin{array}{l}\text { Probstdorfer Saatzucht, Austria } \\
\text { Tamadur }\end{array}$ \\
IS Duragold & $\begin{array}{l}\text { Pstropstdorfer Saatzucht, Austria } \\
\text { Slovakia }\end{array}$ \\
\hline
\end{tabular}

*Line selected by the authors from line HTC 2083.

spike, kernel weight per spike, and spike length. The grain yield per $1 \mathrm{ha}$, expressed in terms of $\mathrm{tha}^{-1}$, was estimated based on the yield per plot.

The approximate chemical composition of the grain was determined according to the methods described by Wiwart et al. (2013) and Bieńkowska et al. (2020). The grain samples were ground in a Cyclotec 1093 sample mill (FOSS, Denmark). The crude protein content ( $\mathrm{N}$ x 5.7) (Hoseney 1994) was determined in two replications using the Büchi system (K-424 Digestion Unit and B-324 Distillation Unit, Switzerland). Crude fat was extracted using the Soxhlet method (Büchi Extraction System B-811, Switzerland) from $2.5 \mathrm{~g}$ analytical samples of air-dried ground grain, using diethyl ether as a solvent (POCh Gliwice, Poland), extractor capacity $-100 \mathrm{ml}$. The extraction was carried out at a temperature of $60^{\circ} \mathrm{C}$ for $4 \mathrm{~h}$, in two replications. The solvent was evaporated, and solvent caps containing crude fat were dried for $2 \mathrm{~h}$ at $105^{\circ} \mathrm{C}$ in a desiccator and then weighed. The crude fibre content was determined using the Fibertec 2010 system (FOSS, Denmark) and the Weende method. Ground samples of $2 \mathrm{~g}$ were placed in FOSS crucibles with P2 porosity $(40-100 \mu \mathrm{m})$. The samples were placed in a hot extraction unit, immersed in $1.25 \% \mathrm{H}_{2} \mathrm{SO}_{4}$ (POCh Gliwice, Poland) and boiled for $40 \mathrm{~min}$. The sulfuric acid was removed, the samples were rinsed three times with hot demineralized water, placed in a cold extraction unit and rinsed with acetone (POCh Gliwice, Poland). The samples were dried at $105^{\circ} \mathrm{C}$ for $3 \mathrm{~h}$, and the amount of fibre was determined using a quantitative analysis. 
a

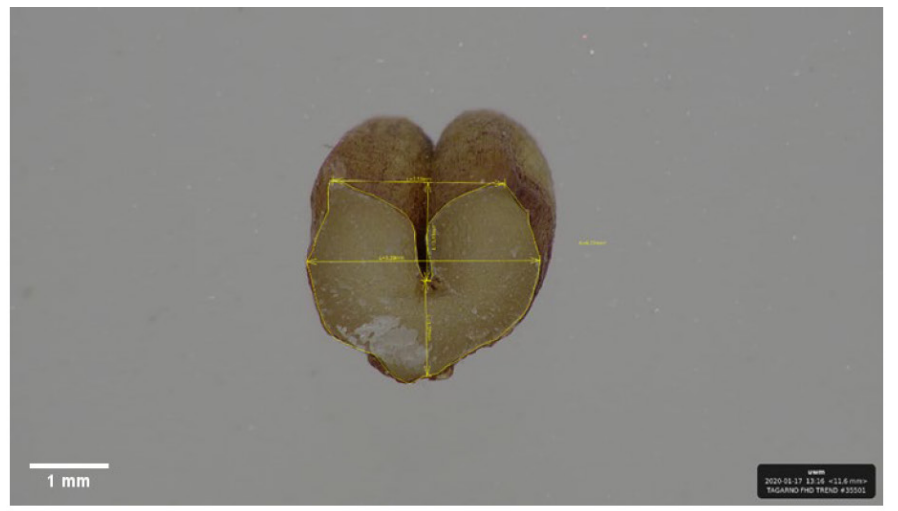

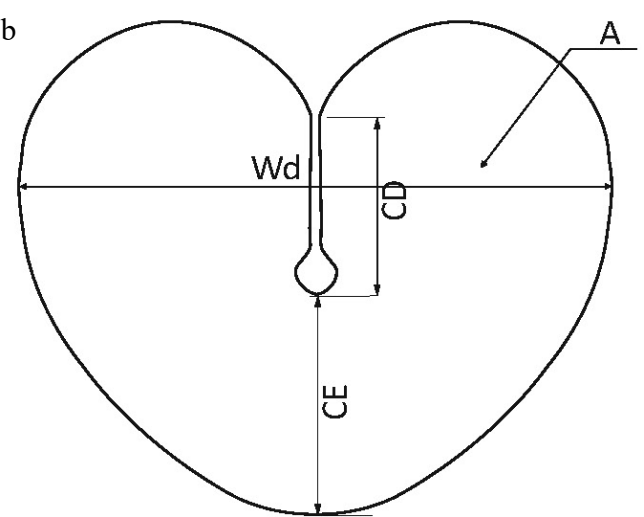

Fig. 1. Original microscopic image of a kernel cross-section with an indication of the measured parameters (a), diagram of the horizontal cross-section of a kernel and the measured shape descriptors (b). A - total cross-sectional area, CD - crease depth, CE - distance from the bottom of the crease to the kernel edge, $\mathrm{Wd}$ - cross-sectional width at the widest point.

The single kernel characterization system (SKCS 4100, Perten) measures single kernel weight, width and hardness with a greater speed than other existing methods. The sample size was 300 kernels, and measurements were performed in duplicate.

A digital image analysis was conducted according to the method described by Goriewa-Duba et al. (2018) and the images were processed using the ImageJ program (Rasband, 2016).

The following descriptors which are defined by regions of interest (ROI) were determined in images of individual kernels: area $(\mathrm{Ae})\left(\mathrm{mm}^{2}\right)$, perimeter $(\mathrm{PE})(\mathrm{mm})$, circularity (CI), Feret diameter (FD), minimal Feret diameter (MFD), and aspect ratio (AR) (Goriewa-Duba et al., 2018).

The horizontal cross-sections of the kernels were examined under the Tagarno Trend digital microscope (Tagarno, Denmark). The kernels were sliced manually with a scalpel in the central part, perpendicular to the crease, and four shape descriptors were measured: total cross-sectional area (A), total cross-sectional width (Wd), distance from the bottom of the crease to the kernel edge (CE) and crease depth (CD) (Fig. 1).

The results were processed statistically using STATISTICA 13.3 software (StatSoft, USA). The significance of the differences between the means was estimated using Tukey's test. A simple correlation analysis and principal component analysis (PCA) were performed for all results.

\section{RESULTS}

The nutrient content of the grain and the main yieldrelated traits are presented in Table 2. Tritordeum grain had a significantly higher protein content $(16.92 \%)$ than T. durum grain (15.54\%). This parameter ranged from $15.35 \%$ (line HTC 1324 ) to $19.30 \%$ (line HT 352 ) in tritordeum grain, and a lower degree of variation was noted in durum wheat grain, from $14.64 \%$ ( $c v$. Tamadur) to $16.70 \%$ (cv. Duragold). The degree of variation in the pro- tein content of the grain was relatively low, and the relative standard deviation (RSD) values were determined at $8 \%$ in tritordeum and 7\% in durum wheat. Tritordeum grain was also significantly more abundant in fat $(2.22 \%)$ than durum wheat grain $(1.93 \%)$, and its fat content ranged from $1.70 \%$ (line HTC 2083') to $2.66 \%$ (line HT 440). Similar differences were noted in average ash content which reached $2.50 \%$ in tritordeum grain and $2.17 \%$ in $T$. durum grain. The grain of both species also differed significantly in fibre content $(1.74 \%$ in tritordeum and $1.22 \%$ in $T$. durum). In the studied breeding lines, fibre content ranged from $1.48 \%$ (line HTC 2060) to $2.65 \%$ (line HTC 2083').

The compared cereals did not differ significantly in spike length or spike weight. Spike length in the studied tritordeum breeding lines and T. durum cultivars is presented in Figs 2,3 . The RSD value for spike length was high at a value of $27 \%$. The average spike length was $7.79 \mathrm{~cm}$ in the tritordeum lines and $5.80 \mathrm{~cm}$ in the durum wheat cultivars. The longest and heaviest spikes were noted in line HTC 2083' (14.16 cm and $3.85 \mathrm{~g}$, respectively), the shortest spikes were observed in lines HT 440 and HT $129(6.51 \mathrm{~cm}$ and $6.63 \mathrm{~cm}$, respectively), whereas lines HT 352 and HT 438 were characterized by the lightest spikes ( $1.55 \mathrm{~g}$ and $1.73 \mathrm{~g}$, respectively).

The number of spikelets per spike (NSS) was a highly differentiating trait, and it was determined at 18.88 in the tritordeum lines (from 14.73 in line HTC 1324 to 27.27 in line HTC 2083') and at 14.38 in the durum wheat cultivars (14.07 to 14.60) (Table 2). The studied cereals did not differ significantly in kernel number and weight per spike. The kernel number per spike (NKS) was highest in line HTC 2083' (77.60) and lowest in lines HT 129 (25.00) and HT 438 (30.20). The average kernel weight per spike was only marginally higher in tritordeum $(1.59 \mathrm{~g})$ than in $T$. durum $(1.41 \mathrm{~g})$, and it was highest in line HTC 2083' (2.43 g). The tritordeum plants were significantly taller than the T. durum plants ( 63.71 and $54.87 \mathrm{~cm}$, respectively), and line HTC 2083' was characterized by the tallest plants $(88 \mathrm{~cm})$. 


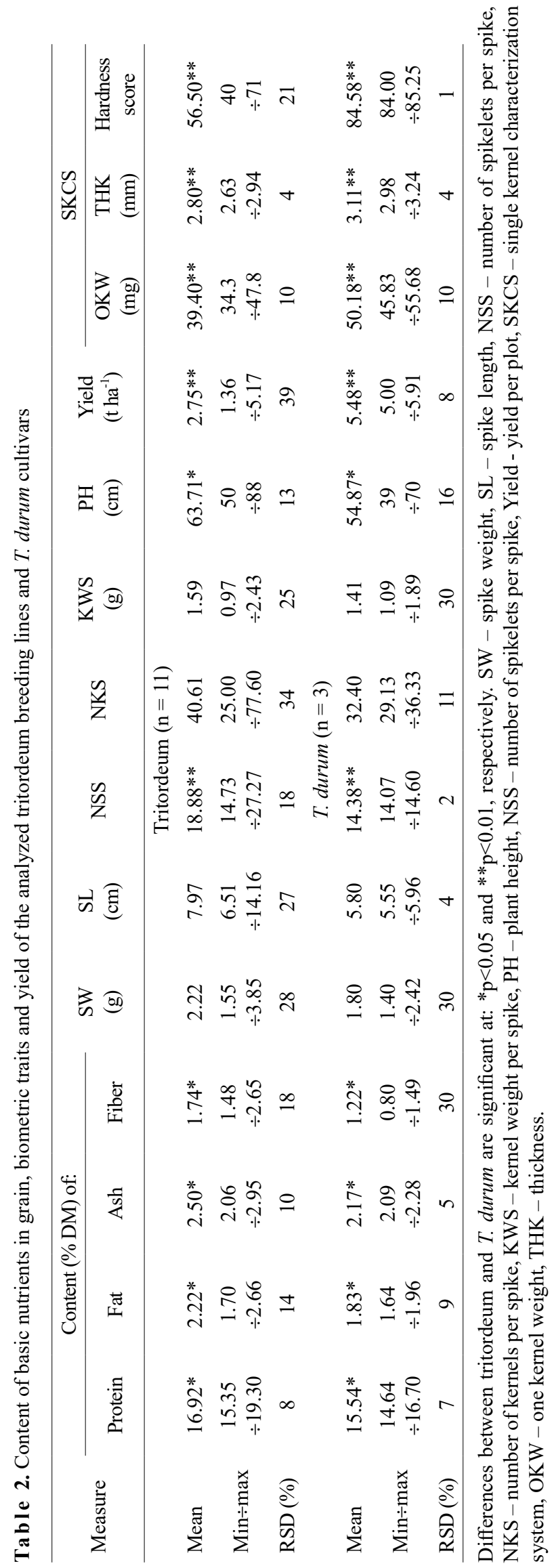

Durum wheat cultivars were characterized by a significantly higher yield potential $\left(5.48 \mathrm{t} \mathrm{ha}^{-1}\right)$ than tritordeum $\left(2.75 \mathrm{t} \mathrm{ha}^{-1}\right)$. Among the analysed breeding lines, the highest productivity was noted in line HTC $1324\left(5.17 \mathrm{t} \mathrm{ha}^{-1}\right)$ which did not differ significantly from the reference cultivars in this respect.

In the SKCS analysis, significant differences between the three parameters were observed for the tritordeum and T. durum grains. Durum wheat kernels were significantly harder than the tritordeum kernels (84.58 vs. 56.50). Hard grain is required to produce high-quality semolina and pasta. The reference cultivars were also characterized by significantly thicker kernels $(3.11 v s .2 .80 \mathrm{~mm})$ and a significantly higher OKW (50.18vs. $39.40 \mathrm{mg})$ than the tritordeum lines.

A heat map and the results of the hierarchical clustering of eight grain parameters in all tritordeum lines and T. durum cultivars are presented in Fig. 4. Four main clusters were identified. Cluster I contained three tritordeum lines with the lowest hardness scores and the highest content of ash, protein and fat. Cluster II included six lines with average values for the analysed parameters. Cluster III only consisted of line HTC 2083' which differed significantly from the remaining genotypes. The grain of line HTC 2083' was characterized by the highest fibre content, a very low fat content, the highest kernel weight per spike, and high OKW. Cluster IV was formed by three T. durum cultivars and line HTC 1324. These objects were characterized by a high yield per unit area, high hardness scores, and a low content of ash, protein, fat and fibre (in particular $c v$. Tamadur). These results point to the considerable differences between tritordeum lines and $T$. durum cultivars.

The horizontal cross-sections of tritordeum and durum wheat kernels are presented in Figs 5, 6. The low hardness scores of tritordeum grain in the SKCS test are supported by images of the starchy endosperm. Tritordeum has soft and lightly-coloured endosperm, which facilitates grain milling. The lowest hardness scores were noted in the grain of lines HT 129 and HT 440 (40 and 41, respectively), which points to the presence of starchy endosperm (Fig. 6). Lines HTC 1324 and HT 444 were characterized by the highest hardness scores ( 71 and 69 , respectively) and the smaller proportions of the light-coloured areas denoting starchy endosperm (Fig. 5). For the durum wheat $c v s$. Tamadur and Duragold (with hardness scores of 84.00 and 84.50, respectively), in particular $c v$. Floradur (with a hardness score of 85.25 ), the kernel cross-sections were practically devoid of light-coloured areas (Fig. 6). The starchy endosperm is the largest portion of the kernel, and its parameters determine the processing quality of the grain. Kernels with hard endosperm have vitreous cross-sections due to high endosperm density, the absence of air pockets and the low content of the protein matrix. The presence of empty areas at the base of the crease was observed in the cross-sectional images of kernels in lines HT 440, JB3, HT 438, HTC 1324 


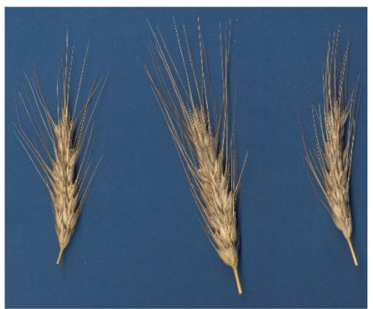

b

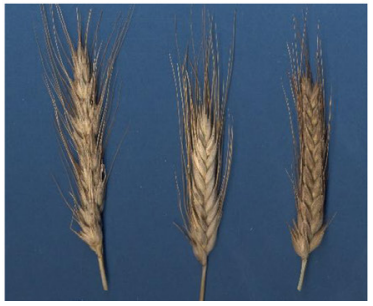

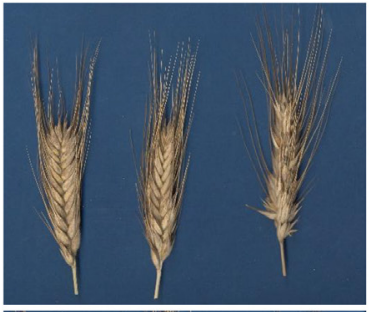

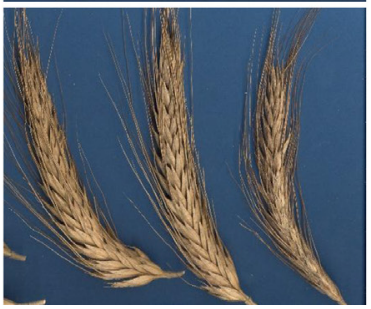

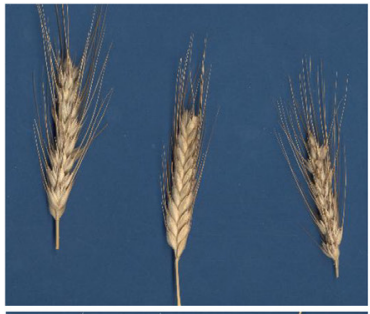

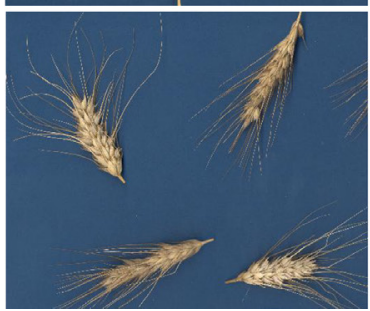

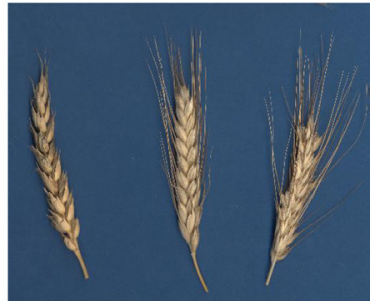

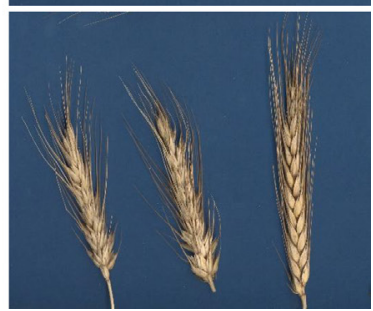

Fig. 2. Spikes of the evaluated tritordeum lines: a - HT440, HT129, HT157, JB3. Bottom row, b - HT352, HTC2083', HTC1324, HT438.

a
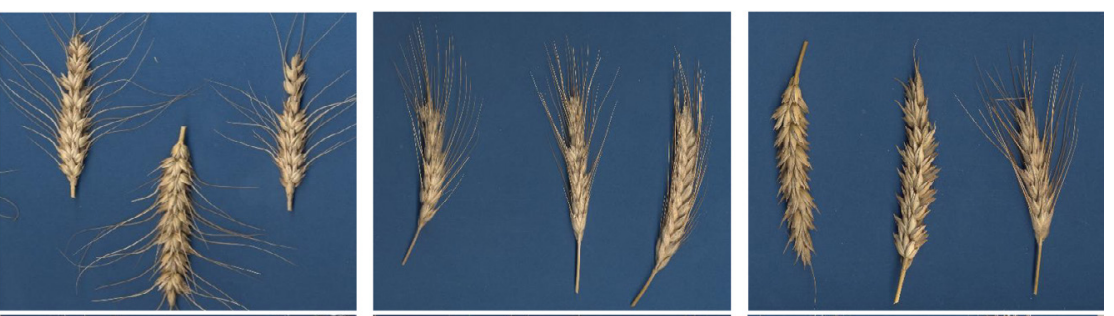

b
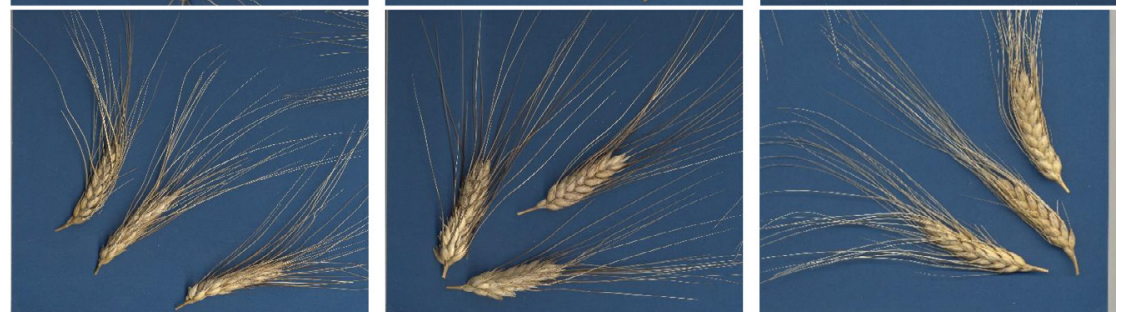

Fig. 3. Spikes of the evaluated cereals: a - tritordeum lines HT444, HTC2060 and HTC2083; b - T. durum cultivars (Floradur, Duragold, Tamadur).

and HTC 2083'. In these kernels, the base of the crease was enlarged, and it formed channels along the longitudinal axis.

The values of the shape descriptors in the kernel crosssections are presented in Table 3. The tritordeum kernels were characterized by a greater degree of variation in all shape descriptors than durum wheat kernels, as demonstrated by the higher RSD values. Crease depth (CD) was the only shape descriptor that did not differ significantly between tritordeum and durum wheat $(1.67 \mathrm{~mm}$ and 1.55 $\mathrm{mm}$, respectively). The average values of the remaining shape descriptors, i.e. cross-sectional area (A), distance from the bottom of the crease to the kernel edge (CE), and cross-sectional width at the widest point (Wd), were significantly higher in durum wheat than in tritordeum. In the group of four analysed shape descriptors, the highest degree of variation was noted in the value of CE (RSD of 35 and $18 \%$ for tritordeum and durum wheat, respectively). The cross-sectional area was more than 25\% larger and the average value of CE was 50\% higher in the T. durum than in the tritordeum grain, which clearly indicates that the durum wheat kernels were larger than the tritordeum kernels.

The variation in shape descriptors was significantly lower in whole kernels than in kernel cross-sections (Table 4). The RSD values ranged from $4 \%$ for MFD to $12 \%$ for AR in the tritordeum lines, and from $1 \%$ for MFD to $4 \%$ for FD and $\mathrm{A}$ in the T. durum cultivars. Significant differences between durum wheat and tritordeum were only noted in the average value of MFD (3.45 and $3.16 \mathrm{~mm}$, respectively), which indicates that the tritordeum kernels were significantly narrower than the durum wheat kernels. In addition to the average value of FD, which was higher (but not significantly) in the tritordeum lines than in the durum wheat cultivars (7.29 vs. 7.16), this suggests that the tritordeum kernels were more elongated than the durum wheat kernels. In addition to the smaller cross-sectional area, the tritordeum kernels were also characterized by a smaller surface area. 


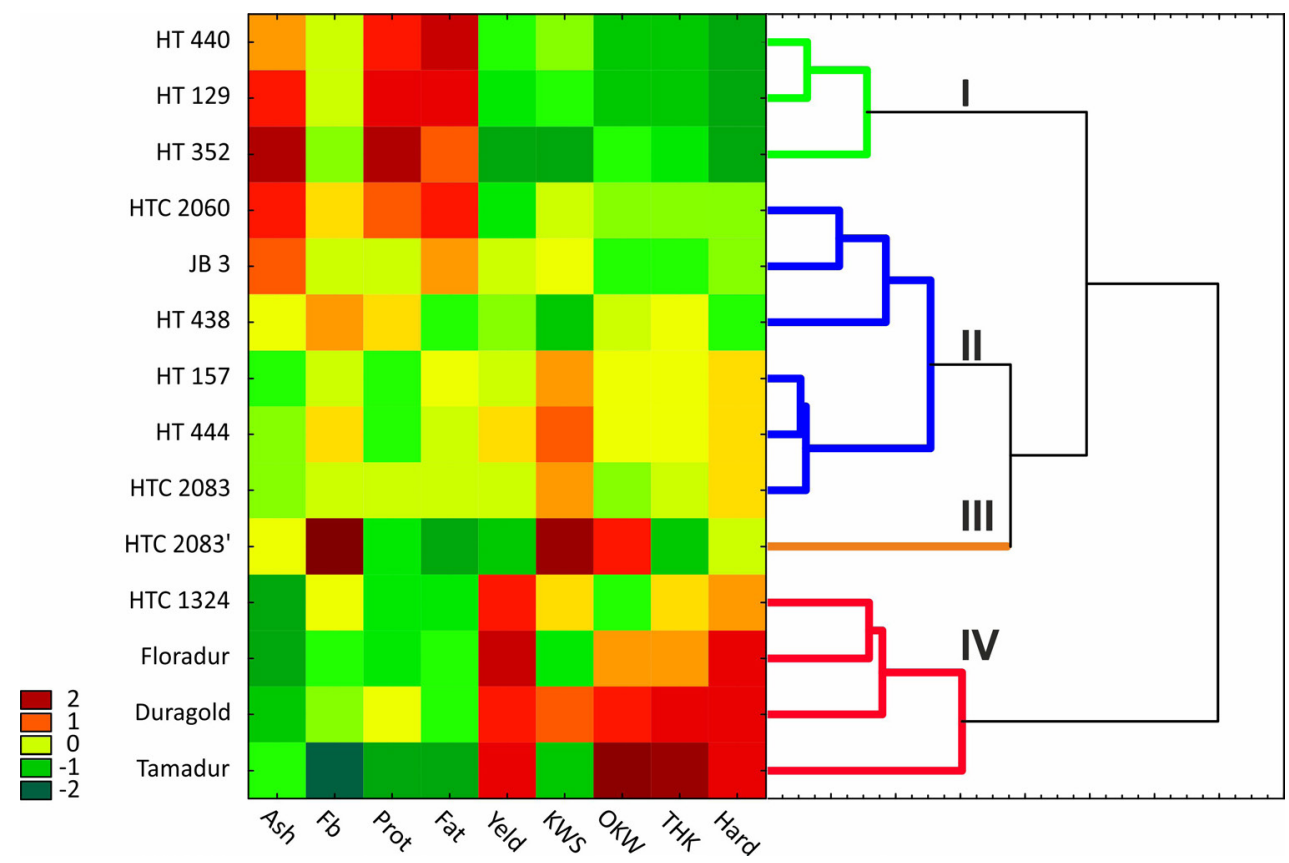

Fig. 4. Heat map and the results of hierarchical clustering for 11 tritordeum breeding lines, three T. durum cultivars (Floradur, Duragold and Tamadur) and grain parameters: Ash, Fb, Protein and Fat - ash, fibre, protein and fat content of grain, respectively; Yield - yield $\left(\mathrm{t} \mathrm{ha}^{-1}\right)$; KWS - kernel weight per spike; OKW - one kernel weight; THK - kernel thickness, Hard - hardness score; I...IV - main clusters.

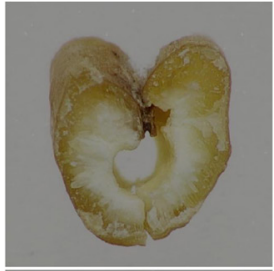

b

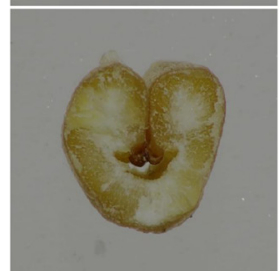

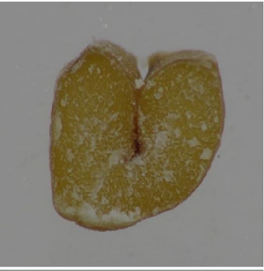

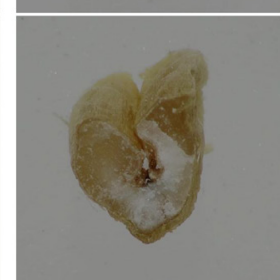

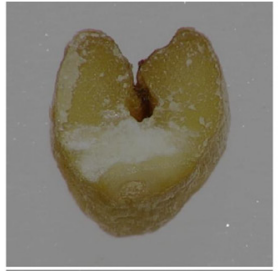

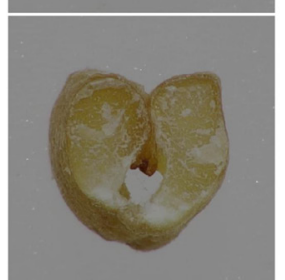

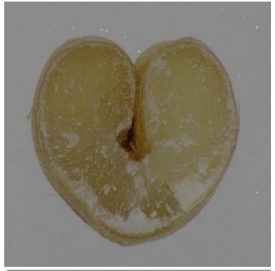

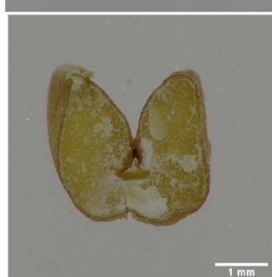

Fig. 5. Images of kernel cross-sections in the analysed tritordeum lines: a - HT440, HT129, HTC2060 and HT157; b - HTC2083', JB3, HTC1324 and HT438.
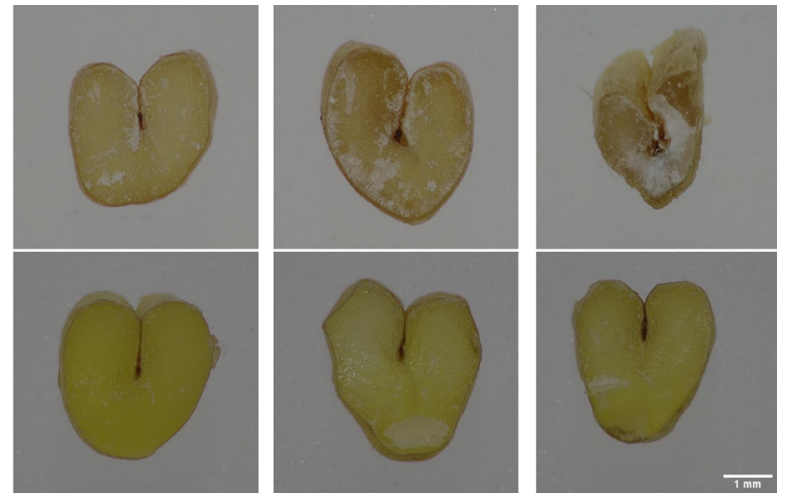

Fig. 6. Images of kernel cross-sections in the analysed cereals: a - tritordeum lines HT444, HTC2083 and HTC2083'; b - T. durum cvs. Floradur, Duragold and Tamadur. 
Table 3. Mean values, relative standard deviation (RSD) and range $(\min \div \max )$ of shape descriptors in the cross-sectional images of kernels of the analyzed tritordeum lines and T. durum cultivars

\begin{tabular}{lcccc}
\hline Measure & $\begin{array}{c}\mathrm{A} \\
\left(\mathrm{mm}^{2}\right)\end{array}$ & $\begin{array}{c}\mathrm{CD} \\
(\mathrm{mm})\end{array}$ & $\begin{array}{c}\mathrm{CE} \\
(\mathrm{mm})\end{array}$ & $\begin{array}{c}\mathrm{Wd} \\
(\mathrm{mm})\end{array}$ \\
\hline \multicolumn{5}{c}{ Tritordeum $(\mathrm{n}=11)$} \\
Mean & $6.39^{* *}$ & 1.67 & $1.10^{* *}$ & $2.98^{*}$ \\
Min $\div$ max & $3.90 \div 9.21$ & $1.10 \div 2.47$ & $0.44 \div 1.96$ & $2.32 \div 3.64$ \\
RSD \% & 18 & 22 & 35 & 11 \\
& \multicolumn{4}{c}{ T. durum $(\mathrm{n}=3)$} \\
Mean & $8.04^{* *}$ & 1.55 & $1.65^{* *}$ & $3.27^{*}$ \\
Min $\div$ max & $6.37 \div 9.05$ & $1.24 \div 2.00$ & $0.91 \div 1.93$ & $2.91 \div 3.67$ \\
RSD \% & 11 & 15 & 18 & 7 \\
\hline
\end{tabular}

A - cross-sectional area, CD - crease depth, CE - distance from the bottom of the crease to kernel edge, $\mathrm{Wd}$ - cross-sectional width at the widest point, differences between tritordeum and T. durum are significant at $* \mathrm{p}<0.05$ and $* * \mathrm{p}<0.01$, respectively.

Only significant values of the correlation coefficient $r$ for the content of basic macronutrients in grain, grain yield and in the geometric properties of kernels are presented in Table 5. The closest correlations between nutrient content and the geometric properties of kernels were noted for protein, ash and fat content. It is interesting to note that these three nutrients were not significantly correlated with the shape descriptors of kernel cross-sections, excluding ash content and cross-sectional width $\mathrm{Wd}$, where $\mathrm{r}$ reached 0.725. These results indicate that the lines with the lowest ash content were also characterized by the lowest values of $\mathrm{Wd}$. Positive correlations were noted between protein content $v s$. PE and FD $(\mathrm{r}=0.672$ and 0.718 , respectively), whereas close negative correlations were observed between the hardness score $(r=-0.931)$, MFD $(r=-0.718)$ and CI $(\mathrm{r}=-0.773)$, which suggests that wider and more spherical kernels were less abundant in protein than in elongated kernels. Grain yield was most closely correlated with ker- nel thickness $(r=0.802)$, hardness score $(r=0.768)$, Wd $(\mathrm{r}=0.760)$ and $\mathrm{CI}(\mathrm{r}=0.662)$. Therefore, lines with a low hardness score were characterized by wide kernels whose shape approximated a sphere. Interestingly, OKW was only significantly correlated with protein, fibre and fat content, and it was not correlated with any shape descriptor. Kernel hardness, an important qualitative trait, was positively correlated with CI and MFD ( $\mathrm{r}=0.757$ and 0.764 , respectively) and negatively correlated with AR $(r=-0.756)$, which implies that wide and spherical kernels had high hardness scores.

The PCA results for all tritordeum lines, durum wheat cultivars and 23 phenotypic traits are presented in Fig. 7. There are significant correlations between the variables and the principal components, variable contributions to $\mathrm{PC} 1$ and PC2 are presented in Table 6. The first two PC values explained $74.5 \%$ of the total variance, which suggests that the tritordeum lines and the durum wheat cultivars can be reliably identified based on the analysed traits. Four groups of objects were identified. The first cluster contained three T. durum cultivars with high values for the hardness score, Yield, CI, THK, MFD, Wd and CD (Table 6). The second, contrasting group included six tritordeum lines (HT438, JB3, HT 440, HT129, HT352 and HTC2060) with a high protein and ash content. The third cluster consisted of four lines (HT44, HT157, HTC1324 and HTC2083) characterized by relatively tall plants, a high spikelet number per spike, a small area and perimeter. These lines were somewhat more abundant in protein, fat and ash than T. durum cultivars, and they were characterized by a very high ash content. The fourth cluster only contained line HTC2083' which differed significantly from the remaining objects in terms of the highest values of SL, SNS, KNS and KWS. In general, variables with high loadings for PC1 had a greater discriminatory power than variables with high loadings for PC2, in particular fibre content, spike length and the kernel number per spike (Table 6).

Table 4. Mean values, relative standard deviation (RSD) and range (min $\div \max )$ of shape descriptors in whole kernels of the analyzed tritordeum lines and T. durum cultivars

\begin{tabular}{|c|c|c|c|c|c|c|}
\hline Measure & $\operatorname{Ae}\left(\mathrm{mm}^{2}\right)$ & $\mathrm{PE}(\mathrm{mm})$ & $\mathrm{CI}$ & $\mathrm{FD}(\mathrm{mm})$ & MFD (mm) & AR \\
\hline & \multicolumn{6}{|c|}{ Tritordeum $(n=11)$} \\
\hline Mean & 17.73 & 17.87 & 0.70 & 7.29 & $3.16^{*}$ & 2.38 \\
\hline $\operatorname{Min} \div \max$ & $15.07 \div 18.49$ & $15.27 \div 19.04$ & $0.64 \div 0.81$ & $5.84 \div 8.00$ & $2.94 \div 3.37$ & $1.79 \div 2.71$ \\
\hline \multirow[t]{2}{*}{ RSD $\%$} & 6 & 6 & 7 & 8 & 4 & 12 \\
\hline & \multicolumn{6}{|c|}{ T. durum $(\mathrm{n}=3)$} \\
\hline Mean & 19.23 & 17.95 & 0.75 & 7.16 & $3.45^{*}$ & 2.10 \\
\hline $\operatorname{Min} \div \max$ & $18.48 \div 20.14$ & $17.45 \div 18.54$ & $0.73 \div 0.76$ & $6.90 \div 7.44$ & $3.40 \div 3.48$ & $2.02 \div 2.16$ \\
\hline RSD\% & 4 & 3 & 2 & 4 & 1 & 3 \\
\hline
\end{tabular}

Ae - area, PE - perimeter, CI - circularity, FD - Feret diameter, MFD - minimal Feret diameter, AR - aspect ratio; significant difference at $* \mathrm{p}<0.01$. 


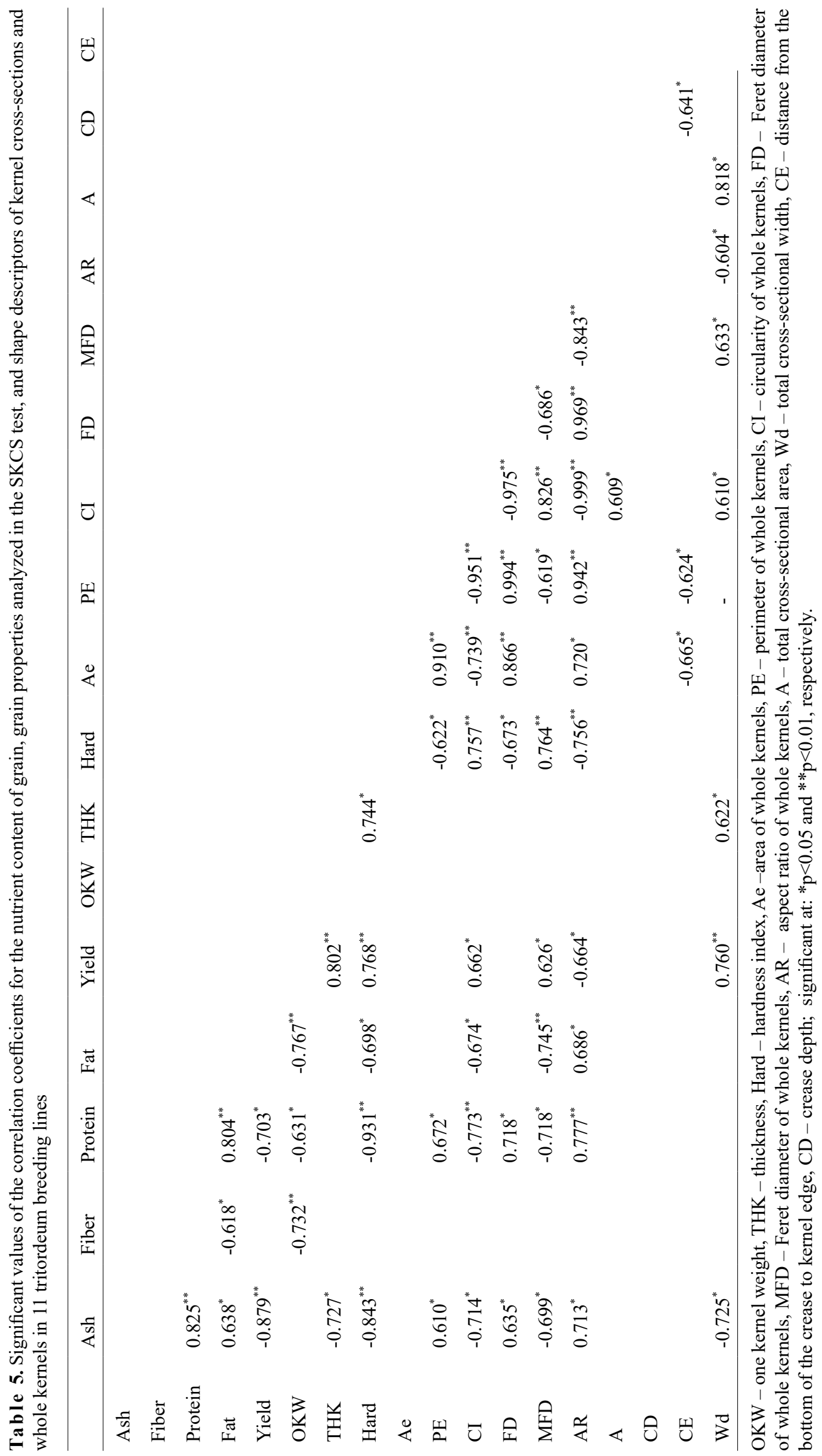




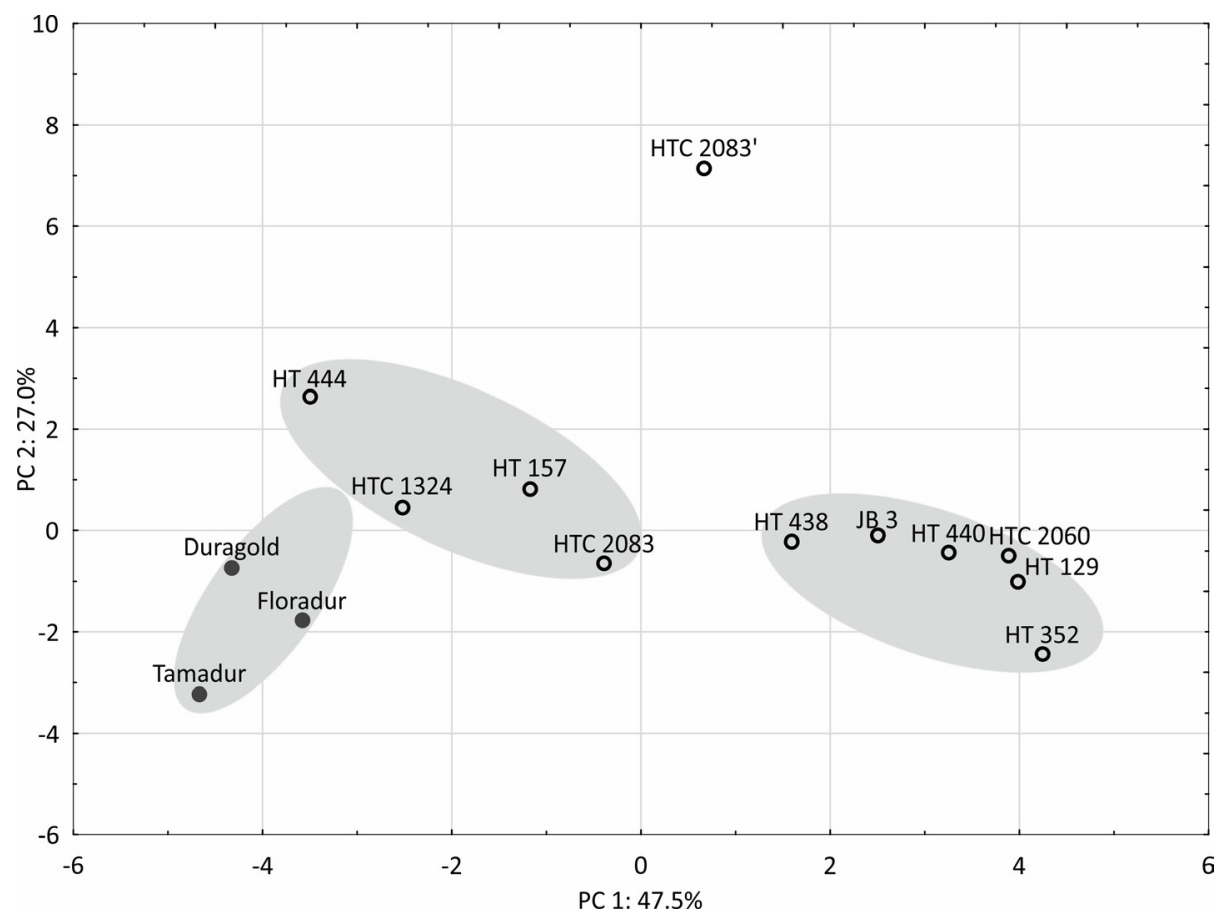

Fig. 7. PCA results for tritordeum breeding lines, T. durum cultivars and analysed traits (refer to Table 6). Confidence Gaussian ellipses were drawn to represent a probability of 0.66 .

\section{DISCUSSION}

Phenotypic variation was compared in 11 breeding lines of spring tritordeum and three cultivars of spring durum wheat that are presently grown in Europe. The continuous reduction in the genetic variability of major crops, including cereals, poses a serious threat to agriculture. In many countries, fewer varieties that are well adapted to a wide range of environmental conditions are being bred to reduce the costs of seed production, maintenance and marketing (Atienza et al., 2008). Therefore, the continuous search for new sources of variability in traits of interest has strategic importance in the production of leading crop species. Hybrids of genetically distant taxa, such as genera, create entirely new possibilities for generating genetic diversity. Triticale, which is presently grown in various regions of the world, is the best example of genetic engineering success. Breeding efforts to cross wheat and barley have been made since the beginning of the twentieth century (Farrer, 1904). Tritordeum has been shown to possess favourable agronomic traits such as a suitability for biomass production, seed size, protein content, yield and harvest index, and it also has the potential to become a new crop for food processing (Martin, 1988a). Tritordeum was originally developed in 1980 (Martin, 1988b; Padilla and Martin, 1987) and the first cultivar was registered in the EU Common Catalogue of varieties and agricultural plant species in 2012 (https:// cpvoextranet.cpvo.europa.eu/mypvr/\#!/en/publicsearch).

Research into the performance, environmental and agronomic requirements of tritordeum was initiated nearly 30 years ago (Gallardo and Fereres, 1993), but the species is still regarded as a novel crop. Tritordeum's performance in Central Europe has not been studied extensively to date. Previous research focused on the content of bioactive compounds, mainly carotenoids, the technical quality of tritordeum grain for the food processing industry (Eliášová and Paznocht, 2017; Giordano et al., 2019; Lachman et al., 2018) and the cytogenetics of tritordeum (Delgado et al., 2017). Very few studies have explored the morphological and anatomical features of tritordeum kernels and their correlations with the content of basic nutrients, the present study was undertaken to fill in this knowledge gap. Durum wheat was selected as the reference material because it is a parental component of tritordeum. For this reason, the performance and agronomic traits of tritordeum were compared with those of T. durum despite considerable differences in the processing quality of both cereals.

The chemical composition of grain is influenced mainly by genetic and environmental factors, and it is the main determinant of the nutritional value of cereals. The protein content of grain is one of the most important traits that imparts nutritional value to grain and influences the quality of flour-based products (Balyan et al., 2013). Large and heavy kernels have a larger endosperm and a smaller proportion of aleuronic layers and external pericarp (Arzani and Ashraf, 2016). Similar observations were made in this study, as demonstrated by the significant negative correlations between protein content $v s$. grain yield $(r=-0.703)$ and OKW ( $\mathrm{r}=-0.631)$. The close negative correlations between OKW vs. fat $(\mathrm{r}=-0.767)$ and fibre $(\mathrm{r}=-0.732)$ content are logical and to be expected. Kernel size is mainly determined 
Table 6. Values of the correlation coefficient describing the relationship between variables and PCs and variable contributions to the first two PCs for the studied tritordeum lines, T. durum cultivars and traits

\begin{tabular}{|c|c|c|c|c|c|}
\hline \multirow{2}{*}{ Trait } & \multicolumn{2}{|c|}{ Variable - $\mathrm{PC}^{*}$} & \multicolumn{3}{|c|}{ Variable contributions } \\
\hline & PC 1 & PC 2 & PC 1 & PC 2 & $\begin{array}{c}\Sigma \text { for } \mathrm{PC} 1 \\
\text { and } \mathrm{PC} 2\end{array}$ \\
\hline Ash & 0.897 & & 0.074 & 0.001 & 0.075 \\
\hline Fiber & & 0.886 & 0.011 & 0.127 & 0.138 \\
\hline Protein & 0.820 & & 0.061 & 0.013 & 0.074 \\
\hline Fat & 0.775 & & 0.055 & 0.011 & 0.066 \\
\hline Yield & -0.897 & & 0.074 & 0.014 & 0.088 \\
\hline $\mathrm{SL}$ & 0.867 & & 0.003 & 0.121 & 0.124 \\
\hline NSS & 0.564 & 0.669 & 0.029 & 0.072 & 0.101 \\
\hline KNS & 0.939 & & 0.000 & 0.142 & 0.142 \\
\hline KWS & 0.852 & & 0.005 & 0.117 & 0.122 \\
\hline OKW & -0.730 & & 0.049 & 0.000 & 0.049 \\
\hline THK & -0.852 & & 0.066 & 0.026 & 0.092 \\
\hline Hard & -0.940 & & 0.081 & 0.001 & 0.082 \\
\hline $\mathrm{PH}$ & & 0.721 & 0.010 & 0.084 & 0.094 \\
\hline $\mathrm{Ae}$ & & -0.659 & 0.000 & 0.070 & 0.070 \\
\hline $\mathrm{PE}$ & 0.566 & -0.581 & 0.029 & 0.054 & 0.083 \\
\hline CI & -0.891 & & 0.073 & 0.017 & 0.090 \\
\hline FD & 0.687 & & 0.043 & 0.044 & 0.087 \\
\hline MFD & -0.908 & & 0.075 & 0.000 & 0.075 \\
\hline $\mathrm{AR}$ & 0.898 & & 0.074 & 0.015 & 0.089 \\
\hline A & -0.810 & & 0.060 & 0.016 & 0.076 \\
\hline $\mathrm{CD}$ & & & 0.017 & 0.042 & 0.059 \\
\hline $\mathrm{CE}$ & -0.755 & & 0.052 & 0.001 & 0.053 \\
\hline Wi & -0.801 & & 0.059 & 0.013 & 0.072 \\
\hline
\end{tabular}

*Only values significant at $\mathrm{p}<0.01$ are presented in the table. Other explanation as in Table 4.

by the size of the starchy endosperm. An increase in the proportion of starchy endosperm reduces the size of the embryo which accumulates most lipids (Arzani and Ashraf, 2016). An increase in kernel size decreases the ratio of pericarp area to volume. Fibre is not evenly distributed in cereal kernels. The outer layers, i.e. the seed coat and the aleurone layer, are most abundant in fibre (Shewry et al., 2013). The health benefits of fibre have been well documented (Gebruers et al., 2008). Therefore, the relatively high content of fibre in the grain of the studied tritordeum lines (in particular line HTC 2083') is a highly desirable trait. A high fibre content and the presence of other compounds with health benefits indicate that tritordeum grain is well suited for the production of functional foods.

The physical properties of grain, in particular its morphological and anatomical traits as well as its hardness score, play an important role during harvest, storage and processing because they determine the processing quality of grain (Gaines et al., 1997; Haddad et al., 1999). Hexaploid tritordeum has been analysed for processing quality and compared with wheat and triticale, the results indicate that in terms of quality, tritordeum grain is more similar to bread wheat than durum wheat and triticale. This suggests that tritordeum is more suitable for breadmaking than pasta making (Martín et al., 1999). Interestingly, hexaploid tritordeum $(2 n=6 x=42$, HchHchAABB) lacks the $D$ genome which is associated with the viscoelastic properties of bread wheat dough. The hardness score is one of the most important traits for pasta production. Durum wheat grain does not contain puroindolines, which are proteins that are responsible for the grain hardness of bread wheat (Guzmán and Alvarez, 2014; Morris, 2002) and yet it has a very hard texture. Grain texture influences not only milling and processing operations, but also culinary applications (Morris et al., 2019). A highly significant difference in hardness scores was noted between the cereals analysed, which suggests that the grain of the examined tritordeum lines is not suitable for pasta production. Similar observations were made by previously cited authors (Martín et al., 1999). The significantly lower values of OKW and kernel thickness in tritordeum lines as compared to durum wheat cultivars are also responsible for the lower flour yield due to the broad ratio of kernel surface area to kernel volume. The relationship described above is responsible for the higher bran yield during grain milling. According to Visioli et al. (2020) the thousand kernel weight is always lower in tritordeum than in durum wheat regardless of the production system.

The crease depth and crease shape are also important determinants of the processing quality of the grain. A deep crease increases the share of pericarp in the kernel volume, and it compromises the milling quality of the grain. A deep crease on the ventral side may also promote the growth of fungal pathogens, including toxigenic fungi of the genus Fusarium (Ropelewska and Zapotoczny, 2018). The observation of horizontal kernel cross-sections revealed that in several lines, the crease expanded and formed a channel along the entire kernel length. This feature may contribute to the growth of mould fungi, including Fusarium fungi. A deep and widening crease is not desirable because it compromises the milling quality of grain and increases the risk of contamination with Fusarium toxins. The absolute difference in crease depth between the studied tritordeum lines and the reference $T$. durum cultivars was not significant, but the distance from the bottom of the crease to the kernel edge (CE) was much greater in durum wheat. The $\mathrm{CD} / \mathrm{CE}$ ratio reached 1.06 in durum wheat, but only 0.66 in tritordeum, therefore, the relative crease depth was $60 \%$ larger in tritordeum. This trait also negatively affects the milling quality of grain. 
In the group of the analysed shape descriptors, MFD was the only parameter that differed significantly between tritordeum and durum wheat. Lower MFD values were indicative of a smaller kernel width in tritordeum. It is interesting to note that significant negative correlations were observed between MFD vs. ash $(\mathrm{r}=-0.699)$, protein $(\mathrm{r}=$ $-0.718)$ and fat $(r=-0.745)$ content, but a positive correlation was noted between MFD and grain yield $(r=0.626)$.

An analysis of simple correlations between shape descriptors and the remaining kernel attributes produced interesting results. One kernel weight was not bound by significant correlations with any shape descriptor in images of whole kernels or kernel cross-sections. This parameter was significantly (negatively) correlated only with protein, fibre and fat content. The presence of significant positive correlations between CI vs. MFD and yield suggests that lines with wide and spherical kernels have a higher yield potential. This observation is indirectly supported by the strong positive correlation between THK and yield ( $\mathrm{r}=$ 0.802). In turn, kernels with a large cross-sectional area (A) and cross-sectional width (Wd) were also characterized by a spherical shape, as demonstrated by high CI values $(r=0.609$ and 0.610 , respectively). Shape descriptors in cross-sectional images were not correlated to a significant extent with the content of basic nutrients. The only exception was $\mathrm{Wd}$ which was significantly correlated with ash content $(r=-0.725)$. A very close negative correlation was also noted between the hardness score and protein content $(r=-0.931)$. This is a typical result in SKCS analyses (Randhawa et al., 2015). The results of the experiment were subjected to a multi-dimensional analysis which revealed three major trends. Firstly, all tritordeum lines differed considerably in terms of the examined phenotypic traits. It is interesting to note that the cluster closest to the durum wheat cluster contained only 4 of the 11 investigated breeding lines (36\%). The remaining lines were characterized by completely different values of the investigated traits. Secondly, fibre content, spike length, spikelet number per spike, and kernel number and weight per spike made the greatest contributions to both PCs. The total contribution of each variable to both PCs exceeded 0.1. In turn, OKW, whole kernel area, crease depth and distance from the bottom of the crease to the kernel edge made the most minor contribution to both PCs. The total contribution of each variable to both PCs was less than 0.07 , however, both boundary values were selected arbitrarily. Thirdly, line HTC 2083' selected from HTC 2083 differed completely from the remaining lines in all of the investigated traits. This line was most effectively identified based on parameters that were positively correlated with $\mathrm{PC} 2$, i.e. fibre content, plant height and spikelet number per spike. Although tritordeum is suitable for breadmaking, a further improvement in quality is required for hexaploid tritordeum to be used as a crop for human consumption (Alvarez and Martin, 1994; Alvarez et al., 1995). According to Cubero et al. (1986) and
Martin (1988 a,b), tritordeum could be used as a protein source crop, and the results of this study confirm this observation. Furthermore, the protein content of cereals is also an important determinant of the quality of the end product (Martin et al., 2000). Field experiments or the laboratory analysis of tritordeum have not been carried out in Poland to date. The only research concerning the performance of tritordeum in Central and Central-Eastern Europe was conducted in the Czech Republic (Lachman et al., 2018; Martinek et al., 2003; Phuong et al., 2017). These studies focused on the processing quality of grain and the content of nutrients with health benefits. In the present study, an attempt was made to determine the phenotypic variation in spikes and kernels, and the results were compared with those produced by the reference cultivars of durum wheat. Both cereals showed a preference for somewhat higher temperatures during the growing season than bread wheat and barley, and they are relatively tolerant to drought. The area under $T$. durum cultivation continues to increase steadily in Central Europe, and tritordeum may be expected to attract the interest of breeders and food producers.

\section{CONCLUSIONS}

1. The results of this study clearly indicate that in the conditions of Central Europe tritordeum grain can accumulate more than $8 \%$ protein and $43 \%$ more fibre than durum wheat.

2. Tritordeum is certainly a promising cereal species despite the fact that the yield potential of the analysed breeding lines is half of that of modern $T$. durum cultivars. The high content of protein and fibre in Tritordeum grain is associated with low values in the shape descriptors of the cross-sectional image of grains. They indicate the higher ratio of pericarp area to kernel volume and a deeper furrow than in T. durum. Similar challenges had to be overcome by triticale breeders in the 1970s and 1980s, when triticale was a novel cereal with relatively low yields and several undesirable traits. However, due to considerable breeding progress, triticale has emerged as a valuable and highyielding crop in recent decades.

\section{ACKNOWLEDGMENT}

The authors would like to thank Professor Antonio Martín of the Institute of Sustainable Agriculture in Córdoba, Spain, and Ing. Petr Martinek of the Agricultural Research Institute Kroměříž Ltd. in the Czech Republic for donating breeding lines for this study. We would also like to thank Dr. Dariusz Gontarz for the SKCS analysis and the technical staff of the Department of Genetics, Plant Breeding and Bioresource Engineering for their technical support during the chemical analysis. 
Funding: This research is the result of a long-term study carried out at the University of Warmia and Mazury in Olsztyn, Faculty of Agriculture and Forestry, Department of Genetics, Plant Breeding and Bioresource Engineering, topic number 30.610.007-110.

\section{REFERENCES}

Alvarez J.B., Ballesteros J., Arriaga H.O., and Martin L.M., 1995. The rheological properties and baking performances of flours from hexaploid tritordeums. J. Cereal Sci., 21, 291-299. https://doi.org/10.1006/jcrs.1995.0032

Alvarez J.B. and Martin L.M., 1994. Variation for breadmaking quality characters in several crosses of hexaploid tritordeum (tritordeum Ascherson et Graebner) with a common parent. Cereal Res. Commun., 22, 285-291.

Arzani A. and Ashraf M., 2016. Smart engineering of genetic resources for enhanced salinity tolerance in crop plants. Crit. Rev. Plant Sci., 35, 146-189. https://doi.org/10.1080/07352689.2016.1245056

Atienza S.G., Ramírez M.C., Martín A., and Ballesteros J., 2008. Effects of reciprocal crosses on agronomic performance of tritordeum. Russ. J. Genet., 43(8), 865-868. https://doi.org/10.1134/S1022795407080054

Ballesteros J., Ramirez M.C., Martinez C., Atienza S.G., and Martin A., 2005. Registration of HT621, a high carotenoid content tritordeum germplasm line. Crop. Sci., 45, 26622663. https://doi.org/10.2135/cropsci2004.0641

Balyan H.S., Gupta P.K., Kumar S., Dhariwal R., Jaiswal V., Tyagi S., Agarwal P., Gahlaut V., and Kumari S., 2013. Genetic improvement of grain protein content and other health-related constituents of wheat grain. Plant Breed., 132, 446-457. https://doi.org/10.1111/pbr.12047

Bieńkowska T., Suchowilska E., and Wiwart M., 2020. Triticum polonicum L. as promising source material for breeding new wheat cultivars1. J. Elem., 25, 237-248. https://doi.org/10.5601/jelem.2019.24.2.1873

Bothmer R., Jacobsen N., Baden C., Jorgensen R.B., and Linde-Laursen I., 1995. An Ecogeographical Study of the Genus Hordeum. International Board for Plant Genetic Resources, Svalov, Sweden.

Cubero J.I., Martin A., Millan T., Gomez-Cabrera A., and de Haro A., 1986. Tritordeum: a new alloploid of potential importance as a protein source crop. Crop Sci., 26, 1186-90. https://doi.org/10.2135/cropsci1986.0011183X002600060023x

Delgado A., Carvalho A., Martín A.C., Martín A., and LimaBrito J.E., 2017. Genomic restructuring in F1 Hordeum chilense $\times$ durum wheat hybrids and corresponding hexaploid tritordeum lines revealed by DNA fingerprinting analyses. J. Genet., 96, 13-23. https://doi.org/10.1007/s12041-017-0772-0

Eliášová M. and Paznocht L., 2017. Total phenolic content and antioxidant activity of tritordeum wheat and barley. Agron. Res., 15, 1287-1294.

Erlandsson A., 2010. Tritordeum Evaluation of a New Food Cereal. M.Sc. Thesis, Agricultural Program Food Science, Swedish University of Agricultural Sciences.
Farrer W., 1904. Some notes on the Wheat ,Bobs'; its peculiarities, economic value and origin. Agricultural Gazette N.S.W., 15, 849-854.

Gaines C.S., Finney P.L., and Andrews L.C., 1997. Influence of kernel size and shriveling on soft wheat milling and baking quality. Cereal Chem., 74, 700-704. https://doi.org/10.1094/CCHEM.1997.74.6.700

Gallardo M. and Fereres E., 1993. Growth, grain yield and water use efficiency of tritordeum in relation to wheat. Eur. J. Agron., 2, 83-91. https://doi.org/10.1016/S1161-0301(14)80137-8

Gebruers K., Dornez E., Boros D., Fraś A., Dynkowska W., Bedő Z., Rakszegi M., Delcour J.A., and Courtin C.M., 2008. Variation in the content of dietary fiber and components thereof in wheats in the healthgrain diversity screen. J. Agr. Food Chem., 56(21), 9740-9749. https://doi.org/10.1021/jf800975w

Giordano D., Reyneri A., and Locatelli M., 2019. Distribution of bioactive compounds in pearled fractions of tritordeum. Food Chem., 301,125228. https://doi.org/10.1016/j.foodchem.2019.125228

Goriewa-Duba K., Duba A., Wachowska U., and Wiwart M., 2018. An evaluation of the variation in the morphometric parameters of grain of six Triticum species with the use of digital image analysis. Agronomy, 8, 296.

https://doi.org/10.3390/agronomy8120296

Guzmán C. and Alvarez J.B., 2014. Molecular characterization of two novel alleles of Hordoindoline genes in Hordeum chilense Roem. et Schult. Genet. Resour. Crop Evol., 61, 307-312. https://doi.org/10.1007/s10722-013-0077-y

Haddad Y., Mabille F., Mermet A., Abecassis J., and Benet J.C., 1999. Rheological properties of wheat endosperm with a view on grinding behaviour. Powder Technol., 105, 89-94. https://doi.org/10.1016/S0032-5910(99)00122-9

Hoseney R.C., 1994. Principles of cereal science and technology. American Association of Cereal Chemists (ed.), Inc., St Paul, MN, USA.

Lachman J., Hejtmánková A., Orsák M., Popov M., and Martinek P., 2018. Tocotrienols and tocopherols in colored-grain wheat, tritordeum and barley. Food Chem., 240, 725-735. https://doi.org/10.1016/j.foodchem.2017.07.123

Martin A., 1988a. Tritordeum: The first ten years. Rachis, 7, 1-2. Martin A., 1988b. Tritordeum: The first ten years. Rachis, 7, 12-5.

Martin A., Cabrera A., Hernández P., Ramirez M.C., Rubiales D., and Ballesteros J., 2000. Prospect for the use of Hordeum chilense in durum wheat breeding. In: Durum Wheat Improvement in the Mediterranean Region: New Challenges. CIHEAM, Zaragoza, Spain.

Martín A., Alvarez J.B., Martín L.M., Barro F., and Ballesteros J., 1999. The development of tritordeum: A novel cereal for food processing. J. Cereal Sci., 30, 85-95. https://doi.org/10.1006/jcrs.1998.0235

Martín A. and Sánchez-Monge E., 1980. Effects of the 5B system on control of pairing in Hordeum chilense $\times$ Triticum aestivum hybrids. Z. Pflanzenzüchtg, 85, 122-127.

Martinek P., Ohnoutková L., Vyhnánek T., and Bednář J., 2003. Characteristics of wheat-barley hybrids ( $\mathrm{X}$ tritordeum Ascherson et Graebner) under Central-European climatic conditions. Biuletyn IHAR, 226/227, 87-95. 
Montesano V., Negro D., De Lisi A., Urbano M., Sarli G., and Laghetti G., 2020. Agronomic performance and phenolic profile of tritordeum ( $\mathrm{x}$ tritordeum martinii A. Pujadas) lines. Cereal Chem., 98(1), 1-10. https://doi.org/10.1002/cche. 10378

Morris C.F., 2002. Puroindolines: the molecular genetic basis of wheat grain hardness. Plant Mol. Biol., 48, 633-647. https://doi.org/10.1023/A:1014837431178

Morris C.F., Kiszonas A.M., Murray J., Boehm J.Jr., Mi I., Zhang M., and Cai X., 2019. Re-evolution of durum wheat by introducing the hardness and Glu-D1 Loci. Front. Sustain. Food Syst., 3, 3-6. https://doi.org/10.3389/fsufs.2019.00103

Padilla J.A. and Martin A., 1987. Cytology, fertility, and morphology of amphiploids Hordeum chilense $\times$ tetraploid wheats (tritordeum). Plant Breed., 99, 295-302. https://doi.org/10.1111/j.1439-0523.1987.tb01185.x

Phuong L.M., Lachman J., Kotíková Z., Orsák M., Michlová T., and Martinek P., 2017. Selenium in colour-grained winter wheat and spring tritordeum. Plant Soil Environ., 63, 315-321. https://doi.org/10.17221/259/2017-PSE

Randhawa H.S., Bona L., and Graf R.J., 2015. Triticale breeding - progress and prospect (Ed. F. Eudes). In: Triticale. Springer International Publishing. https://doi.org/10.1007/978-3-319-22551-7_2

Rasband W.S., 2016. ImageJ. U.S. National Institute of Health: Bethesda, MD, USA. https://imagej.nih.gov/ij, Accessed 21 Aug. 2021

Ropelewska E. and Zapotoczny P., 2018. Classification of Fusarium-infected and healthy wheat kernels based on features from hyperspectral images and flatbed scanner images: a comparative analysis. Eur. Food Res. Technol., 244, 1453-1462. https://doi.org/10.1007/s00217-018-3059-7
Shewry P.R., Hawkesford M.J., Piironen V., Piironen V., Lampi A.M., Gebruers K., Boros D., Andersson A.A.M., Åman P., Rakszegi M., Bedo Z., and Ward J.L., 2013. Natural variation in grain composition of wheat and related cereals. J. Agric. Food Chem., 61, 8295-8303. https://doi.org/10.1021/jf3054092

StatSoft. STATISTICA (Data Analysis Software System). Version 13; StatSoft, Inc.: Tulsa, OK, USA, 2014. Available online: www.statsoft.com

Vaquero L., Comino I., and Vivas S., 2018. Tritordeum: a novel cereal for food processing with good acceptability and significant reduction in gluten immunogenic peptides in comparison with wheat. J. Sci. Food Agric., 98, 2201-2209. https://doi.org/10.1002/jsfa.8705

Villegas D., Casadesús J., Atienza S.G., Martos V., Maalouf F., Karam F., Aranjuelo I., and Nogués S., 2010. Tritordeum, wheat and triticale yield components under multi-local mediterranean drought conditions. Field Crops Res., 116, 68-74. https://doi.org/10.1016/j.fcr.2009.11.012

Visioli G., Lauro M., Vamerali T., Dal Cortivo C., Panozzo A., Folloni S., Piazza C., and Ranieri R., 2020. A comparative study of organic and conventional management on the rhizosphere microbiome, growth and grain quality traits of tritordeum. Agronomy, 10(11), 1717.

https://doi.org/10.3390/agronomy 10111717

Wiwart M., Suchowilska E., Kandler W., Sulyok M., Groenwald P., and Krska R., 2013. Can Polish wheat (Triticum polonicum L.) be an interesting gene source for breeding wheat cultivars with increased resistance to Fusarium head blight? Genet. Resour. Crop Evol., 60, 2359-2373. https://doi.org/10.1007/s10722-013-0004-2 